\title{
ENSURING THE FUNCTIONING OF SYSTEM ANALYSIS IN JURISPRUDENCE WHILE INTEGRATING ANALYTICAL METHODS OF PROCESSING LARGE DATA SETS
}

\section{Zaiets O.M.}

\section{INTRODUCTION}

Today, Ukraine has not only entered the world information space, but has become an integral part of it. This opened the way to virtually unlimited information resources for government and commercial institutions that conduct information and analytical research, which is a necessary component for the organization of work in this direction. However, apart from undeniable achievements, our country has encountered some trends that pose a real threat to the national interests of the state. That is why building the information field of Ukraine in the world information space is not only a matter of prestige but also of national security.

In the course of large-scale socio-political changes in Ukraine that are reflected in the implementation of legal reforms, the legal system is raised to the level of problems directly related to the solution of urgent problems of legal regulation.

The interest in studying the possibilities of systematic analysis in jurisprudence and the integration of analytical methods of processing large data sets, in particular normative legal acts, is becoming more and more intensive in domestic law. The latest developments, as a rule, concentrate on the analysis and evaluation of the legal technology embedded in the Ukrainian reality. Outside the discussion are the general issues of the essence and functioning of the analytical knowledge of the system of law, in particular the rules and principles of their construction, conditions of effectiveness, principles of co-organization in an effectively operating system, conditions of "transfer" from one legal system (industry) to another, mechanisms of functioning and interaction.

Legal science (jurisprudence, jurisprudence - from the Latin jurisprudential) is one of the oldest social sciences. Even ancient Greek philosophy developed the most important theoretical issues of law. The problems of law play an important role in the modern democratic society and in the formation of the rule of law, which contributes to the fact that legal science occupies one of the leading places among the social sciences ${ }^{1}$.

${ }^{1}$ Дубовицкий В.Н. Социология права: предмет, методология и методы. Минск : Право и экономика, 2010. С. 12. 
The importance of legal technology for legal science is that, by demonstrating the connection and unity of all elements of a particular phenomenon, it allows you to understand its nature, varieties and, thus, to know the legal reality. Exploring the possibilities of legal technology will help to gain a more generalized and in-depth knowledge of specific legal relationships.

In order to increase the efficiency of the work of state bodies, it is necessary to improve the use of legal techniques and technologies. IT and artificial intelligence is by far the most popular area of research for scientists, the most profitable in the field of business and the area that has the most impact on human life - jurisprudence, because artificial intelligence is now being implemented in all spheres of human life, and, changes it accordingly ${ }^{2}$.

The field of law is also linked to all spheres of human life and cannot stand apart from the development of technological progress and artificial intelligence. This area can and should be an assistant to the legal profession.

The information flows include the following main types of information material:

- open periodicals and other scientific and technical, domestic and foreign publications;

- closed publications of public authorities, research institutions and higher education institutions;

- translations of scientific and technical foreign publications;

- manuscript works deposited;

- dissertations, reports on research robots, their registration and registration cards;

- reports on the results of basic and exploratory research;

- Official publications and publications of the State Patent Office concerning domestic and foreign patents and licenses;

- publications with information about inventions and innovative proposals that are distributed for centralized use;

- legal acts, methodological and regulatory documents;

- archival and museum documents and scientific and informational materials.

\section{Sources of informational data arrays for analytical processing}

The aforementioned information materials on different types of media (paper, magnetic, optical, etc.) in conjunction with the reference and search apparatus form help-information funds, specialized funds of governing bodies,

\footnotetext{
${ }^{2}$ Сырых В.М. Логические основания общей теории права : В 2 т. Т. 1: Элементный состав. 2-е изд., испр. и доп. М.: Юридический Дом “Юстицинформ”, 2001. С. 133.
} 
research institutions, and higher education institutions and constitute the Unified Distributed Information Fund (hereinafter referred to as ERDIF). ERDIF is completed in accordance with the information needs related to the scientific and technical activities of the research institutions, higher education institutions and scientists. Recording ERDIF should provide for a rational distribution of sources of information, both by topic and by type of document. According to the ERDIF structure, books, brochures, periodicals and other information materials are compiled in different types of media with a total number of more than 3873801 publications (documents). Of these, books account for $84 \%$, brochures $15 \%$, and periodicals (by number of publications) and other information materials $-1 \%$. By types of publications by purpose, the fund can be divided into official publications (laws, decrees, decrees, orders, directives, military statutes) $0,5 \%$, scientific publications (reports on research, monographs, theses, dissertations, materials of scientific conferences (seminars), collections of scientific works) $-3,5 \%$, educational publications (textbooks, manuals and tutorials, lectures, advisers, rules, instructions, monuments) $-68 \%$, reference publications $-1,6 \%$, information publications $-26,4 \%^{3}$.

Nowadays, IT technologies help to free a person from a routine job that does not require a specialist and have specialized knowledge, systematize information, process large amounts of information, work with large databases and more. Also, the latest information technologies are able to process and work with information that requires special knowledge and skills, which is also a significant area of its use.

All this can be used in the work of legal representatives.

For example, law firms, like any other, today cannot exist without IT technology and artificial intelligence to work in the office, but it can be more productive to use, such as creating custom programs for drafting standard forms of contracts, letters, lawsuits and other legal documents. Not all clients of law firms require the preparation of individual documents, for a large number of clients it is sufficient to have a standard document, but given its standard needs and drafted in accordance with the law. All these parameters can be applied in a special program for the preparation of standard documents, which is also the cost of primary legal aid. This will allow the lawyer or lawyer to use their time to work more intelligently, to compose and solve tasks that require high skills and mental ability, to solve non-standard tasks. It will also allow all sections of the population to enjoy legal assistance, which will have a positive impact on society in general and legal relations in society.

3 Біленчук П.Д., Кофанов А.В., Кобилянський О.Л., Міщенко В.Б. Інформаційна аналітика в юриспруденції: автоматизовані системи і технології. Навчальний посібник. Київ: ННІПСК КНУВС, 2009. С. 11. 
Law firms already exist today, for example, to develop programs for predicting the outcome of a court case. This trend is in demand and assists the lawyer in his work, according to the developers themselves. They are now testing and processing this system, its performance and results.

The fact that a lawyer has been engaged in the development of such a program indicates that the work of a lawyer requires modernization and change with time, and it is the representatives of the legal profession who are interested in these changes.

The judicial system of Ukraine is already actively taking advantage of IT technologies and artificial intelligence in its work. We already use a special site to get acquainted with the necessary information, we can make the necessary payment without spending our time to visit the bank, we can submit some documents electronically, we can use an electronic signature to draft and submit some documents, we plan to use typical lawsuits, examples which will be posted on the site and used in simple cases, which also allows a person not to consult a lawyer but to obtain the necessary legal protection. For example, in accordance with the Order of the State Security Administration of Ukraine dated December 22, 2018 No. 628 "On conducting testing of the subsystem "E-court" in local and appellate courts operation of subsystem "E-court" in test mode has started.

In accordance with the requirements of section XI of the Regulation on the automated system of court documents circulation, the acceptance and registration of the procedural documents sent to the court by the participants of the court process should be done from the official electronic addresses (E-cabinets), which they should create in the E-court located at the link: https:// cabinet.court.gov.ua

According to Part 6 of Art. 6 of the Code of Civil Procedure of Ukraine are obligatory in the Unified Court Information and Telecommunication System (ESITS) their official electronic addresses are registered by lawyers, notaries, judicial experts, state bodies, local self-government bodies and economic entities of the state and communal sectors of economy. Other persons register their official e-mail addresses in the Unified Court Information and Telecommunication System on a voluntary basis. However, taking into account the requirements of section XI of the Regulation on the automated system of court documents circulation for the acceptance and registration of procedural documents sent to the participants of the trial, any registration and processing of procedural documents sent by participants of the process to the court without e-mail addresses (Electronic cabinets) created in ESITS will not be tried by a court.

The procedure provides for obtaining their own electronic digital signature, because, according to clause 2 of part 8 of Article 6 of the Civil 
Procedure Code of Ukraine, the submission of procedural and other documents, the execution of other procedural actions in electronic form solely with the help of ESITS, is possible only with the use of their own electronic digital signature.

\section{Innovative technologies in processing large data arrays}

IT technologies and artificial intelligence take away a part of a person's technical work and leave time to perform the intellectual and professional part. For example, when accountants developed special programs to carry out their core business, it was an invaluable contribution to their work. Now no one understands how it was possible to work without these programs. The same contribution can be made to the work of legal professionals, such as, for example, automatic drafting of standard documents, document analysis, forecasting, and the like.

In the near future, according to scientists, artificial intelligence will help the elderly, and all the people who want it, will replace people at airports, hotels and other public places. "Smart homes" will be created to serve all people's needs. Medicine will be more advanced with artificial intelligence, created surgeon robots (Da Vinci Surgical System) is a two-unit unit, the first designed for the surgeon-operator, and the other, a four-handed robot manipulator, is an actuator, one of the hands holding a camcorder that transmits the image of the operated area, the other two in real-time reproduce the movements performed by the surgeon, and the fourth "hand" performs the functions of an assistant surgeon a), for example, will not be tired and make mistakes. This should also change the direction of legal practice. For example, in New York, an artificial intelligence detective uncovered several crimes. The Patternizr algorithm analyzes employee reports to find connections and commonalities between different theft and robbery cases. This helped identify one person who committed these crimes. Patternizr now analyzes 600 violations a week. The algorithm compares new cases with previous cases, revealing similarity in many parameters. The program handles unstructured textual descriptions of events in search of the information it needs. So far, this work has been done by analysts. However, they had neither access to the tens of thousands of reports nor the ability to process them so quickly. Also, artificial intelligence does not tire, it does not need a break for rest and sleep. Artificial intelligence is capable of processing vast amounts of information in a very short time. He can also do important, but not interesting, human work, monotonous, but perform it at a high level.

The ability to find hidden patterns is the strengths of algorithms. It is used not only by police, but also by scientists - from chemists to astronomers. 
The unrestrained development of technology is an integral part of people's lives today, it has given development to all spheres of our lives, and the legal profession needs to be "in time" and not keep up with it.

The development of artificial intelligence also influences the development of new areas of law. For example, the European Parliament adopted a resolution on "Civil Law on Robotics". The document deals with various aspects and problems of robotics and artificial intelligence. It proposes to lay down the legal bases for the use of artificial intelligence and the introduction of a Pan-European system for the registration of "smart" machines, to individual categories of robots should be assigned an individual registration number, which will be entered in a special register, where you can find detailed information about the work, including information about the manufacturer, owner conditions for payment of compensation in case of damage. And the support of the artificial intelligence system and its control should be dealt with by a specialized agency for robotics, which could address other aspects of legal regulation in this area.

Since there are many artificial intelligence programs available today, the leading European states are ready to legislate for a computer program and put artificial intelligence on a par with the human. In Japan, in 2016, at a meeting of the State Commission on Intellectual Law, lawmakers made the decision to begin developing regulatory documents on copyright protection for products of creative activity created by artificial intelligence. According to the commission, such a move should be a support for companies working on innovation creation and implementation.

The emergence and development of artificial intelligence has led to the emergence of a new line of law, one of the most common in the future. With the development of these technologies, new objects and subjects of law emerge, new legal relationships, a new scope of law, and, as a result, new specialists in the field of law will be needed.

Technological progress is not a bad situation, but it must be borne in mind that nothing like this has happened before, and all processes existing in society must be changed, including legal relations between man and artificial intelligence.

In the future, artificial intelligence will be required as an "electronic person" as a participant in public relations, and this may be quite natural for the future. It is customary for lawyers and society to recognize a legal entity (which is, in fact, a product of human thought, a virtual entity whose social status is based only on the collective myth prevailing in the legal sphere), a fully-fledged subject of social relations with its own rights and obligations. plump.

In the field of criminal law, the activity of a legal entity was considered only through its representatives - individuals who were supposed to be 
criminally responsible for their dangerous acts or omissions and their consequences, now the traditional aspects have been changed and legal measures of a legal nature have been normatively fixed (fine, liquidation, etc.), which have all the features of punishment under the Criminal Code of Ukraine (Section XIV1 Measures of Criminal Law of Legal Entities).

Thus, criminal law, like any other law, is not a dogma, a religion in its frozen sense, and it can be modified in accordance with the times, the development of society and the emergence of new relationships.

The most developed countries of the planet (USA, Norway, Denmark, United Arab Emirates, Federal Republic of Germany, State of Israel, People's Republic of China, Grand Duchy of Luxembourg, French Republic, Swiss Confederation, etc.) are increasingly using different industries. Even today, they are actively introducing these technologies to improve and optimize their analytical work.

In general, analytical work requires first and foremost a continuous systematization of the incoming data. The analyst examines, weighs and evaluates fragmentary information on the basis of which he creates promising, well-founded forecasts. In addition, the responsibilities of the analyst include: analysis of existing thoughts on the problem being studied, verification of previously made assumptions, evaluation of alternative scenarios, ongoing coverage of the data.

No country, if it wants to integrate into the global information space, has to stay away from the global processes of increasing the role of information technology. The practical use of multimedia in the information and analytical work of state institutions is an important means of increasing the quality of public administration and developing a positive image of Ukraine in the global information space. At the same time, it is necessary to realize the purpose with which the technologies of multimedia are used in the information-analytical work, and the advantages of concrete choice.

In general, multimedia has many advantages, including the following: numerous software applications; very economical products; ease of adjustment and maintenance; integrity of materials; forming a positive image of a party using multimedia technologies.

The greatest benefit from the introduction of these technologies is the information and analytical work in the state institutes, which can be in the following areas:

- promotion of the information field of Ukraine in the world information space for organization of information-analytical researches;

- development of an information field and formation of a positive image of Ukraine in the world information space; 
- creation of a system of interactive news reporting in information and analytical work;

- low-cost, dynamic, dynamic tools for connecting to think tanks and other sources of information;

- electronic interactive systems of training of analysts ${ }^{4}$.

The obvious inability to have all the journals and books in this specialty in the library of every scientific institution requires the wide knowledge of scholars through various bibliographic directories, and subsequently also through electronic catalogs about the location and order of obtaining the publication. In addition, the information scientist must be able to work with literature. It is necessary to increase the qualification of scientists of all specialties in every possible way, to expand their acquaintance with all kinds of bibliographic manuals. And this activity must become one of the essential elements of the work of all scientific and technical libraries and information bodies, be planned and controlled on an equal basis with others. Information support for research works is more effective, the better the scientists have the technique of finding and using secondary information, they know the enormous possibilities of modern bibliographic manuals. Scientific and technological progress also applies to the library. The introduction of technical innovations has changed the process of bringing information to the user, automation allows you to get copies of the required documents in an automated mode. Optical databases are also widely used at this time. Further enhancement of the effectiveness of the use of information for research should be carried out taking into account the results of the analysis.

At present, the leading institution that defines policy in the field of scientific-information and information-analytical activity is: in Ukraine Ukrainian Institute of Scientific, Technical and Economic Information (Ukrintei).

The leading institution of Ukraine is the Ukrainian Institute of Scientific, Technical and Economic Information (UkrINTEI). The basic direction of scientific activity of UkrINTEI is theoretical and practical bases of creation of system of information-analytical support of scientific-technological and innovative development of Ukraine. Research is conducted in the following sections:

1. Scientific and methodological bases of creation of system of information-analytical support (IAZ) of scientific-technological and innovative development (STI) of Ukraine;

4 Біленчук П.Д., Кофанов А.В., Кобилянський О.Л., Міщенко В.Б. Інформаційна аналітика в юриспруденції: автоматизовані системи і технології. Навчальний посібник. Київ: ННІПСК КНУВС, 2009. С. 33. 
1.1. Scientific and methodological bases of creation of information resource for information-analytical support;

2. Creation of an integrated database system for the functioning of the system of information and analytical support of scientific and technological and innovative development;

3. Development of regulatory and organizational documents for the system of information and analytical support;

4. Organization of interfaces of internal and external access to the resources of the IAZ STIR system;

5. Organization of functioning and use of the information-analytical support system;

6. Integration of the STI system into the world information space 5 .

Complex technical systems are material systems that, according to certain algorithms but without human involvement, solve predefined tasks.

They include the following variables in work technology: when and where the task should be performed, how the task should be performed, what is the relationship between the tasks performed. Complex sociotechnical systems are systems whose constituent is a human operator, knowledge, skills, moods, value preferences and relation to the performed duties of which in interaction with a technical device in the process, for example, production of material values, control of certain processes, processing information, etc., help increase the efficiency of solving certain tasks or improve their performance.

\section{Systematic approach in the general methodological basis of the creation of complex sociotechnical systems}

The concept of socio-technical systems was developed by English scientists E.Trist and K.Bemforth of the Thevistock Institute of Public Relations, who were engaged in the study of the mechanization of coal production in the UK. The results obtained allow us to conclude on the interconnection and interdependence of the two parts of the holistic system technical, represented by tools and equipment and social, which includes people, relations between them and institutional settings, as well as characteristics of the social engineering system, among which are:

1) organizational philosophy based on employees' understanding of their goals and the purpose of the enterprise, their constant willingness to share with the administration all responsibility for the results of business activities;

5 Біленчук П.Д., Кофанов А.В., Кобилянський О.Л., Міщенко В.Б. Інформаційна аналітика в юриспруденції: автоматизовані системи і технології. Навчальний посібник. Київ: ННІПСК КНУВС, 2009. С. 25. 
2) organizational structure of management that provides ordinary workers and employees with real rights to participate in management;

3) a new approach to job development and the role of the executor in the decision-making process;

4) a new scheme of placement of equipment that would meet the needs of a promising form of work organization and provide for the acceleration of material flows in production;

5) new forms and methods of training and retraining, more flexible personnel policy aimed at guaranteeing employment;

6) new criteria in assessing the economic efficiency of using modern technologies and making investments in production development.

One of the most well-known general methodological principles for creating complex sociotechnical systems is a systematic approach ${ }^{6}-$ a direction of methodology of scientific knowledge, based on the consideration of phenomena (processes, objects) as systems, the main stages of which are problem formulation, goal allocation or a set of goals, identification of alternative means by which a goal can be achieved, identification of resources required for the use of each system, construction of a mathematical model, ie a series of dependencies between goals and alternative means to achieve them, the definition of criteria for selecting the best alternative.

The set of specified methodological principles and theoretical provisions of the systematic approach make it possible to view the object of study as a whole system, relatively separated from the external environment and at the same time related to it, ie in close connection and interaction with other objects, to track changes occurring in the system, to study the specific system qualities, to make sound conclusions about the laws of development of the system and to determine the optimal mode of its functioning.

The main tools of a systems approach are system analysis and synthesis. Analysis and synthesis - general scientific methods, without which no act of scientific research can do without, are in the opposite direction (analysis from whole to part, synthesis - from parts to whole) and at the same time inextricably linked methods of cognition ${ }^{7}$.

System analysis is a methodology for the study of such properties and relationships in objects that are difficult to observe and difficult to understand, by presenting these objects in the form of separate components, elements,

${ }^{6}$ Бойко Г.І. Сутність терміну “юридична техніка”. Правове регулювання суспільних відносин: актуальні проблеми та вимоги сьогодення : Матеріали II Міжнародної науковопрактичної конферениї̈ у 4-х частинах (31 березня 2011 р., м. Запоріжжя). Запоріжжя : Запорізька міська громадська організація “Істина”, 2011. Ч. 2. С. 14-16.

${ }^{7}$ Бурячок В.Л., Толюпа С.В., Аносов А.О. та інші. Системний аналіз та прийняття рішень в інформаційній безпеці: підручник. К.:ДУТ, 2015. С. 58. 
features and opposites of purposeful systems, studying the properties and mutual relations of these systems as the relationship between the goals and the means of their realization.

It differs from other research methods in that it: takes into account the fundamental complexity of the object being investigated; takes into account the inability to observe a number of object and environmental properties; takes into account its extensive and stable interconnections with its environment; real phenomena, their properties and connections with the environment are further translated into abstract categories of systems theory; Based on the known properties of complex systems, it is possible to discover new specific properties and interconnections of a particular research object; unlike other methods in which objects are well defined, includes one of the important steps in identifying, finding, or constructing an object; focuses not on solving "correctly formulated" tasks, but on creating the right task statement, choosing the right methods for solving it.

The main thing in system analysis is to find a way that can turn a complex problem into a simpler one, not only difficult to solve, but also to understand, to turn the problem into a sequence of tasks for which there are methods of solving them. System analysis is always specific - it always deals with a specific problem, a specific object of study, and is productive when applied to solving tasks of a certain type. It is usually aimed at solving complex, poorly structured problems, dominated by qualitative, little-known and uncertain sides, caused by:

- lack of understanding of the problem;

- complexity of classification of problems;

- distorted assessment of problems;

- incorrect assessment of the significance of the problems;

- the difficulties of posing problems in the long run;

- blending the goals to be achieved with the means to achieve them.

The purpose of applying system analysis to a specific problem is to increase the validity of the decision being made. Its main function is to distinguish such features of an event that could be taken as a basis for unification, systematization of facts, arrangement of them in an appropriate order (chronological, functional, structural, etc.), which in one way or another characterizes a certain side of the development of the event under study. Systematic analysis establishes opposing properties, trends of events that are parties to certain contradictions and allow to reveal the internal source of the event. The need for it arises when: a new problem is formulated (determined) and its solution requires coordination of goals with many means of achieving them; there are some hard-to-compare options for achieving a coherent set of goals; the problem identified has branched links that produce long-lasting 
effects in different industries, and taking decisions in such cases requires taking into account the overall efficiency and full cost; new complex systems are being created or existing systems are being upgraded and important decisions must be made at a sufficiently long-term perspective in the presence of uncertainty and risk, etc.

To ensure the success of system analysis, you must: apply it where it is intended; need to carry it out, present the purpose and (or) its purpose; feel responsible to him as analysts and the customer; have sufficient information, experience, ideas and ideas about the subject matter of the study; to reflect in the results of system analysis the real state of affairs and the real ways of solving problems, not the "justification" of subjective decisions; have adequate resources (qualified experts, equipment, money); take into account the possible influence of third-party factors (forecast of scientific discoveries, inventions, political situation).

One of the first methods of systematic analysis to determine the order and stages of working with the structure of goals in the process of forecasting and planning was the PATTERN (Planning Assistance Through Technical Evaluation Relevance Number) method developed by RAND Corporation for military research ${ }^{8}$. The main steps of the method are: developing a scenario that is a forecast of the political picture of the world for the planned period; developing a forecast for the development of science and technology (which may be part of the scenario); development of the goal tree by determining the coefficients of relative importance, the coefficients of the state of development and terms, the coefficients of mutual utility; working out the results of the evaluation (calculation of the total coefficients) and providing the results to the decision makers.

\section{CONCLUSIONS}

Thus, the proposed methodology involves the use of law as the main tool for solving social problems. The starting points for its use are, in particular, the understanding that the problems of development of a country are generated by established behaviors, that is, institutions; to change behavior, and therefore to transform institutions, the best and most effective tools are the laws that can and should be used to stimulate a large-scale transformation of society.

So, unlike a number of other concepts, such as: "legislative technique", which is defined as "a system of linguistic and logical receptions, methods, legal procedures and special legal means of legislative activity

${ }^{8}$ Бурячок В.Л., Толюпа С.В., Аносов А.О. та інші. Системний аналіз та прийняття рішень в інформаційній безпеці: підручник. К.: ДУТ, 2015. С. 60. 
of the state apparatus for drafting legal rules in the form of provisions of legislative acts on for the purpose of establishing proper law and order in society "or" the system of legal and linguistic and legal-logical methods, methods and legal-technical procedures of drafting legislative acts by the state apparatus "or more broadly as" the system of legal there, organizational and other procedures of drafting, entering into the legislative body, consideration, examination and adoption of bills, as well as consideration and editing of laws and their entry into force, "lawmaking technique" as a technique of writing texts of drafts of all regulatory acts and editing of texts of all adopted regulatory acts, including bills and laws, "standard design technique", etc. Therefore, all of the definitions listed higher confirm the complexity of the problem of formulating, adopting, and complying with regulatory requirements, which confirms the need to use systematic analysis techniques in jurisprudence and its archival role in the processing of such information.

This technique is applied in many countries of the world. It is developed and taught by experts at the International Consortium for Law and Development (ICLAD), located in Boston, Massachusetts, USA.

\section{SUMMARY}

In the course of large-scale socio-political changes in Ukraine that are reflected in the implementation of legal reforms, the legal system is raised to the level of problems directly related to the solution of urgent problems of legal regulation. System analysis is a complex, multifactorial approach to considering objects of analysis, presenting them in the form of a system that has its elements, connections, structure, functions. The proposed method involves the use of law as the main tool for solving social problems. The starting points for its use are, in particular, the understanding that the problems of development of a country are generated by established behaviors, that is, institutions; to change behavior, and therefore to transform institutions, the best and most effective tools are the laws that can and should be used to stimulate a large-scale transformation of society. Therefore, all of the above arguments demonstrate the complexity of the problem of formulating, adopting and fulfilling the requirements of regulatory acts, which confirms the need to use systematic analysis techniques in jurisprudence and its archival role in the processing of such information. Therefore, all of the definitions listed higher confirm the complexity of the problem of formulating, adopting, and complying with regulatory requirements, which confirms the need to use systematic analysis techniques in jurisprudence and its archival role in the processing of such information. 


\section{REFERENCES}

1. Дубовицкий В. Н. Социология права: предмет, методология и методы. Минск : Право и экономика, 2010. 107 с.

2. Сырых В. М. Логические основания общей теории права : В 2 т. Т. 1: Элементный состав. 2-е изд., испр. и доп. М.: Юридический Дом “Юстицинформ", 2001. 528 с.

3. Біленчук П.Д., Кофанов А.В., Кобилянський О.Л., Міщенко В.Б. Інформаційна аналітика в юриспруденції: автоматизовані системи і технології. Навчальний посібник. Київ: ННІПСК КНУВС, 2009. 47 с.

4. Бурячок В.Л., Толюпа С.В., Аносов А.О. та інші. Системний аналіз та прийняття рішень в інформаційній безпеці: підручник. К.:ДУТ, 2015. 345 c.

5. Андрюшко І.Я. Правове мислення як центральна ланка правової культури. Актуальні проблеми держави $i$ права. 2012. Вип. 63. C. 231-238.

6. Арзамасов Ю.Г., Наконечный Я.Е. Концепция мониторинга нормативных правовых актов. М. : Юрлитинформ, 2011. 200 с.

7. Бойко Г.І. Сутність терміну “юридична техніка". Правове регулювання суспільних відносин: актуальні проблеми та вимоги сьогодення : Матеріали II Міжнародної науково-практичної конферениії y 4-x частинах (31 березня 2011 р., м. Запоріжжя). Запоріжжя : Запорізька міська громадська організація “Істина”, 2011. Ч. 2. С. 14-16.

8. Братівник Я.Г. Система технологій як об’єкт системного аналізу. URL: http://www.nbuv.gov.ua/portal/chem_biol/nvnltu/17_2/270_Bratiwnyk_ 17_2.pdf.

9. Давыдова М.Л. Юридическая техника: проблемы теории и методологи : моногр. Волгоград : Изд-во ВолГУ, 2009. 318 с.

10. Дутко А.О. Юридична техніка : види та зміст. Науковий вісник Львівського державного університету внутрішніх справ. 2006. № 3. C. 25-33.

11. Зайчук О.В., Оніщенко Н.М. Теорія держави і права: Академічний курс : підруч. Київ : Юрінком Інтер, 2006. 253 с.

12. Зыков Д.В. Некоторые вопросы теории юридического мышления. Вестн. Волгогр. гос. ун-та. Сер. 5, Юриспруд., 2012. № 2 (17). C. 274-280.

13. Ковальський В.С., Козінцев І.П. Правотворчість : теоретичні та логічні засади. К. : Юрінком Інтер, 2005. 192 с.

14. Козлов В.Н. Интеллектуальные технологии и теория знаний. СПб. : Изд. Политехнического университета, 2012. 157 с.

15. Онищук I.I. Вдосконалення нормативно-правового регулювання моніторингу якості та ефективності нормативно-правових актів в 
Україні. Наукові записки Інституту законодавства Верховної Ради України, 2017. № 1. С. 7-12.

16. Онищук I.I. Техніка юридичного письма в нормативно-правових актах: монографія. Івано-Франківськ : Лабораторія академічних досліджень правового регулювання та юридичної техніки, 2014. 228 с.

17. Осауленко O.І. Загальна теорія держави і права : навч. посіб. К.: Істина, 2007. $336 \mathrm{c.}$

18. Сурмин Ю.П. Теория систем и системный анализ : учеб. пособ. К.: МАУП, 2003. $368 \mathrm{c.}$

19. Тетяна Фулей, Лора Лукас, Лорна Сайц. Розробка проектів нормативно-правових актів відповідно до методики вирішення проблем. К., ФОП Москаленко О.М., 2012. 180 с.

20. Legislative Drafting for Democratic Social Change. A Manual for Drafters by Ann Seidman, Robert B. Seidman and Nalin Abeysekere. Kluwer Law International, first published, 2001.

21.Zaiets O.M. The Institute for Analytical Support of Pre-trial Criminal Proceedings in Ukraine: current status and prospects of development. European Reforms Bulletin. 2017. № 1. P. 54-62.

22. Zaiets O.M. Application software IBM I2 ANALYST'S NOTEBOOK in law enforcement Ukraine for pretrial investigation of criminal offenses. European Reforms Bulletin. 2016. № 1. P. 69-72.

\section{Information about the author: Zaiets O.M.,}

Candidate of Legal Sciences (PhD), Associate Professor, Professor at the Department of Forensics and Psychology, Odesa State University of Internal Affairs 1, Uspenska str., Odesa, 65014, Ukraine 